\title{
Fungal pneumonia in dogs and cats with pulmonary clinical signs in southern Brazil ${ }^{1}$
}

\author{
Mariana Pavelski², Sandra V. Seixas ${ }^{3}$, José Francisco G. Warth ${ }^{4}$, Cybelle de Souza ${ }^{4}$, \\ Rosangela L. Dittrich ${ }^{4}$ and Tilde R. Froes ${ }^{4}$
}

\begin{abstract}
Pavelski M., Seixas S.V., Warth J.F.G., Souza C., Dittrich R.L. \& Froes T.R. 2018. Fungal pneumonia in dogs and cats with pulmonary clinical signs in southern Brazil. Pesquisa Veterinária Brasileira 38(4):696-702. Departamento de Medicina Veterinária, Universidade Federal do Paraná, Rua dos Funcionários 1540, Curitiba, PR 80035-050, Brazil. E-mail: marianapavelski@gmail.com

Fungal pneumonia has been a differential diagnosis in dogs and cats with pulmonary clinical signs, posting also a public health risk to respective owners. Since a common-source environmental exposure may result in infection, dogs and cats may also act as sentinels for both animal and human disease. Accordingly, the present study has aimed to evaluate the occurrence of fungal pneumonia in dogs and cats with pulmonary clinical signs from May 2013 to February 2015 in southern Brazil. Thoracic radiographs, blood work and non-bronchoscopic Bronchoalveolar Lavage (BAL), followed by cytology and microbiologic analysis were performed in all animals. One dog was positive in the BAL fluid culture for a pathogenic fungus (Cryptococcus neoformans) and another dog to an opportunistic fungus (Candida parapsilosis). Both dogs have presented cough as the prior clinical sign and showed thoracic radiographic changes. In conclusion, the occurrence of fungal pneumonia in southern Brazil in dogs and cats through of this study was relatively low. The BAL fluid culture may allow diagnosis of fungal pneumonia caused by opportunistic or pathogenic fungi and this diagnosis should be a concern in dogs and cats with pulmonary clinical signs.
\end{abstract}

INDEX TERMS: Fungal pneumonia, dogs, cats, southern Brazil, bronchoalveolar lavage, public health, mycoses.

\begin{abstract}
RESUMO.- [Pneumonia fúngica em cães e gatos do sul do Brasil com sinais clínicos pulmonares.] Pneumonia fúngica tem sido um diagnóstico diferencial em cães e gatos com sinais clínicos pulmonares, sendo também um risco de saúde pública para seus respectivos proprietários. Uma vez que uma fonte comum de exposição ambiental pode resultar em infecção, cães e gatos podem agir como sentinelas da doença para ambos, pessoas e animais. Assim, o presente estudo teve como objetivo avaliar a ocorrência de pneumonia fúngica em cães e gatos com sinais clínicos pulmonares, de maio de 2013 a fevereiro 2015 no sul do Brasil. Radiografias torácicas, exame de sangue e lavado broncoalveolar (LBA) não broncoscópico seguido de análise citológica e microbiológica foram realizados
\end{abstract}

\footnotetext{
${ }^{1}$ Received on May 3, 2017.

Accepted for publication on May 16, 2017.

2 Doctoral student, Departamento de Medicina Veterinária, Universidade Federal do Paraná (UFPR), Rua dos Funcionários 1540, Curitiba, PR 80035050, Brazil. *Corresponding author: marianapavelski@gmail.com

${ }^{3}$ Veterinary Hospital Internship, Departamento de Medicina Veterinária, Universidade Federal do Paraná (UFPR), Rua dos Funcionários 1540, Curitiba, PR 80035-050, Brazil.

${ }^{4}$ Professor, Departamento de Medicina Veterinária, Universidade Federal do Paraná (UFPR), Rua dos Funcionários 1540, Curitiba, PR 80035-050.
}

em todos os animais. Um cão foi positivo na cultura do fluido do LBA para um fungo patogênico (Cryptococcus neoformans) e outro cão para um fungo oportunista (Candida parapsilosis). Ambos os cães apresentaram tosse como sinal clínico principal e alterações radiológicas torácicas. Em conclusão, a ocorrência de pneumonia fúngica no sul do Brasil em cães e gatos por meio deste estudo foi relativamente baixa. A cultura do LBA pode possibilitar o diagnóstico de pneumonia fúngica causada por fungos oportunistas ou patogênicos e este diagnóstico diferencial deve ser uma preocupação em cães e gatos com sinais clínicos pulmonares.

TERMOS DE INDEXAÇÃO: Pneumonia fúngica, cães, gatos, sul do Brasil, lavado broncoalveolar, saúde pública, micoses.

\section{INTRODUCTION}

The most common type of pneumonia detected in dogs and cats is caused by bacteria, however, fungal, parasitic and viral pneumonia require a differential diagnosis in patients with respiratory distress (Cohn 2009). Mycotic pneumonia can be caused by Histoplasma capsulatum, 
Blastomyces dermatitidis, Coccidioides immitis, Cryptococcus neoformans and Aspergillus fumigatus. The respiratory tract is a portal of entrance for these organisms and the infection can involve the lungs alone or spread systemically to various target organs (Norris 2004, Hawkins 2014).

Fungal pneumonia is also a concern in humans, an increasing number of affected people with high morbidity and mortality have been described (Richardson 2005, Limper 2010, Silva 2010, Wilson et al. 2002, Brown et al. 2012, Garnacho-Montero et al. 2013, Mandanas \& Byrd 2014). A common-source environmental exposure may result in disease of both animals and humans. The presence of infection in dogs and cats acts as a sentinel for human exposure and potential infection (Greene \& Bromel 2012, Sylkes \& Malik 2012).

Defined geographic locations have been related to certain fungal diseases. Histoplasmosis in humans and animals has a higher incidence in midwestern and the Atlantic United States and may be found in all regions in Brazil; however, in humans, the state of Rio de Janeiro is responsible for most of the microepidemics described (Aidé 2009, Brown et al. 2012, Greene \& Bromel 2012). In dogs and cats the disease is also found in all regions in Brazil (Silva-Ribeiro et al. 1987, Carneiro et al. 2005, Cordeiro et al. 2011, Brilhante et al. 2012, Souza et al. 2015). Blastomycosis is endemic in humans and animals in the central and the southeastern United States, including Ohio and Mississippi Valleys, and in parts of Canada, Africa and India (Bromel \& Sykes 2005, Brown et al. 2012). The incidence of this fungal disease in Brazil is not known. Coccidioidomycosis is found mainly in the southwestern United States, north Mexico and in other dry regions, such as northeastern Brazil (Wanke et al. 1999, Johnson et al. 2003, Togashi et al. 2009). Cryptococcus and Aspergillus are spread worldwide, affecting animals and humans (O'Brien et al. 2004, Marcasso et al. 2005, Richardson 2005, Ferreira 2008, Queiroz et al. 2008, Brown et al. 2012, Pereira et al. 2013).

There are limited studies regarding the incidence of fungal pneumonia in dogs and cats in Brazil. Only two epidemiology studies in dogs were found in the literature, both conducted at a university hospital in Porto Alegre, Rio Grande do Sul $\left(30^{\circ} 2^{\prime} 4.73^{\prime \prime} \mathrm{S} ; 51^{\circ} 13^{\prime} 3.57^{\prime \prime} \mathrm{W}\right)$. One study concerned the occurrence of cryptococcosis, addressing 53 dogs with respiratory clinical signs (Oliveira et al. 2005). Another study concerned the occurrence of pulmonary aspergillosis, addressing 46 dogs with respiratory disorders (Teixeira 2012). No published epidemiological studies were found of fungal pneumonia in cats. Among the case reports of mycotic disease in Brazil, four of these described clinical signs associated with the presence of pneumonia, including one dog with coccidiomycosis (Lorigados et al. 2012), one with aspergillosis (Carvalho 2013), one with cryptococcosis (Paula et al. 2014) and two cats with histoplasmosis (Brilhante et al. 2012, Silveira et al. 2016).

The diagnosis of fungal pneumonia relies on a combination of clinical and physical examination, blood work and thorax radiographs, and other tests may be required (Cohn 2009, Hawkins 2014). Bronchoalveolar lavage (BAL) cytology and culture results may assist in the diagnosis of pulmonary fungal infections (Andreasen 2003, Hawkins 2014).

The lack of studies on the occurrence of fungal pneumonia in clinical practice raises the question as to whether the disease should be a differential diagnosis in dogs and cats with respiratory disorders. To the authors' knowledge, there are no published studies showing the occurrence of fungal pneumonia in dogs and cats in southern Brazil. This study aimed to evaluate the occurrence of fungal pneumonia in dogs and cats attending in a university hospital in Parana state, Brazil and describe the clinical signs, blood work, radiographic findings, and BAL cytology and culture of the positive patients for this disease.

\section{MATERIALS AND METHODS}

Client-owned dogs and cats of any breed or age admitted to the veterinary hospital from May 2013 to February 2015 with clinical signs of lower respiratory diseases such as cough, dyspnea or tachypnea were selected for the study. Animals with respiratory clinical signs but without abnormalities on thoracic radiographs were excluded, also animals that presented masses on thoracic radiographs or increased global heart associated to pulmonary edema or venous congestions suggesting primary heart disease.

The selected dogs and cats involved in the study underwent a physical examination, complete blood count (CBC), thoracic radiography and subsequently non-guided bronchoalveolar lavage. Also, a detailed survey history with environmental characteristics was searched. The study was approved by the local Ethics Committee CEUA 067/2013.

For the radiographic exam, three incidences (ventrodorsal, right and left lateral recumbency) were made following the recommended technique, alignment and overlays (Rudorf et al. 2008). Expiration radiographs were also accepted in this study due to the respiratory restriction of some patients during the examination. The x-rays $(500 \mathrm{~mA})$ for thorax radiography examination were generated by the Neo-Diagnomax ZB-1 (Medicor Budapest, Hungary) and the images (DICOM format) then digitally processed (Agfa CR 30-X, Healthcare, Belgium) and interpreted using K-PACS software (IMAGE Information Systems Ltd, United Kingdom).

Radiographic examinations were interpreted immediately after their acquisition and radiologists were not aware of the laboratory tests or the BAL results. Thorough and careful interpretation of the pulmonary radiographic appearance was performed to detect altered radiopacity and the changes were classified according to lung pattern nomenclature.

The BAL was performed within a maximum 3 days of the thoracic radiograph capture. Animals did not receive any medication during this period. Prior to the BAL, the animals were fast for 8 hours. Then, each animal was sedated with meperidine $(5 \mathrm{mg} / \mathrm{kg})$ followed by anesthesia with propofol ( $4 \mathrm{mg} / \mathrm{kg}$ intravenous). The patients were intubated, positioned in lateral recumbency and $100 \%$ oxygen was provided for $5 \mathrm{~min}$. Then, a sterile siliconized catheter for enteral feeding (adapted by removing the metallic end) adjusted appropriately for the size of the animal was inserted into the tracheal tube, until resistance encountered, next was infused $0.9 \%$ saline solution (up to $5 \mathrm{ml} / \mathrm{kg}$ for dogs and up to $3 \mathrm{ml} / \mathrm{kg}$ for cats), followed by $5 \mathrm{ml}$ of air to prevent the solution remaining in the catheter. In animals with a body weight over $10 \mathrm{~kg}, 20 \mathrm{ml}$ of physiological solution was standardized (Ribas et al. 2010). The infused solution was immediately recovered using a sterile syringe. This sample was stored in an ice-containing cooler, which was sent for laboratory analysis immediately after collection. Blood pressure, heart rate, and pulse oximetry oxygen saturation were monitored throughout the procedure.

BAL fluid (BALF) was processed immediately upon arrival at the laboratory to ensure the preservation of cell morphology and macroscopically characterized for appearance and coloration. Then, a $500 \mu \mathrm{L}$ aliquot was concentrated by cytocentrifugation 
(Cytospin ct14, Teklab ${ }^{\circledR}$, Brazil) at $1500 \mathrm{rpm}$ for 5 min. A differential cell count (cellular differentiation) and searching for fungal hyphae and bacteria were carried out on Romanowsky stained preparations. A total of 400 nucleated cells were counted in order to differentiate alveolar macrophages, foamy alveolar macrophages, lymphocytes, neutrophils, eosinophils, and mast cells. The differential cytology BALF results were compared with normal values previously established for healthy animals. Samples with a cell count below 300 or with Simonsiella sp. (oral contamination) were considered inappropriate and were discarded.

Another sample aliquot was sent to our microbiology laboratory for bacteriological and mycological cultures done following the methodology of Quinn et al. (1994). For bacterial cultures, an aliquot was distributed on plates of blood agar, agar MacConkey, and mannitol agar medium. The plates were then incubated aerobically at $37^{\circ} \mathrm{C}$ for 48-72 hours. After that, in the absence of surface growth, samples were sub-cultured in brain heart infusion broth. Then, bacteria showing predominant growth on the surface of the culture mediums were analyzed for their biochemical characteristics (fermentation or oxidation), and cell morphology by Gram stain and subsequently identified by direct microscopic examination.

For the growth of fungi and yeasts, Sabouraud agar media was used and the plates incubated under aerobic conditions at $28^{\circ} \mathrm{C}$ in a humid BOD (biological oxygen demand) greenhouse for up to 4 weeks; the plates were checked daily. Fungi colonies presenting yeast or mold morphology were identified by direct microscopic examination of colony and hyphae aspects, and the type of budding yeast. The fungi were identified by lactophenol cotton blue stain and Gram stain (for yeasts).

Interpretation of the radiographic examinations, BAL cytology and culture dishes were the consensus of two radiologists, clinical pathologists, and microbiologists, respectively.

\section{RESULTS}

The study comprised 46 animals of several breeds and either sex, including 33 dogs and 13 cats. From these patients, one 6-year-old male Rottweiler (A), and one 5-year-old female mixed breed dog (B) were positive in culture for fungal pneumonia. Dog A was from Ponta Grossa city, Parana state (2505'42"S, 5009'43"W) and dog B was from Caçador city, Santa Catarina state $\left(26^{\circ} 46^{\prime} 31^{\prime \prime}\right.$, $\left.51^{\circ} 00^{\prime} 54^{\prime \prime} \mathrm{W}\right)$. Both used to live in the backyard. None of the cats studied were positive for fungal pneumonia.

Reported clinical signs in $\operatorname{dog} \mathrm{A}$, were a productive cough that had progressed over the past 4 months and progressive nasal discharge over the past 2 months. Dog B presented a chronic cough that had progressed for more than one year. Both dogs had received antibiotics with no success. Dog B had received over one year of oral corticosteroids with temporary improvement of the clinical signs. In the physical examination, dog A presented fever $\left(40^{\circ} \mathrm{C}\right)$, moist crackled auscultation, lymphadenomegaly and hyphema in the left eye. Dog B had crackled auscultation, no fever or other physical abnormalities. The CBC of the dogs were normal and the leukogram revealed a

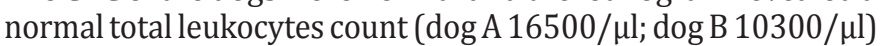
but dog A with neutrophilia.

Radiographic analysis of dog A presented a diffuse mixed pattern with some areas of alveolar consolidation associated with multifocal cavitation and moderate enlargement of the tracheobronchial lymph nodes (Fig.1). The thoracic radiographic findings of $\operatorname{dog}$ A were suggestive of fungal pneumonia, severe bacterial pneumonia or neoplasia. Dog B presented a predominant diffuse bronchial pattern (Fig.2) suggestive of a chronic bronchial disease. There were no complications for either dog, during or after the BAL. No fungal hyphae, yeast or bacteria were visualized in the BALF by microscopic examination. There was an intense quantity of mucus in BALF cytology of dog B. The cytological differential interpretations of the BALF are listed in Table 1.

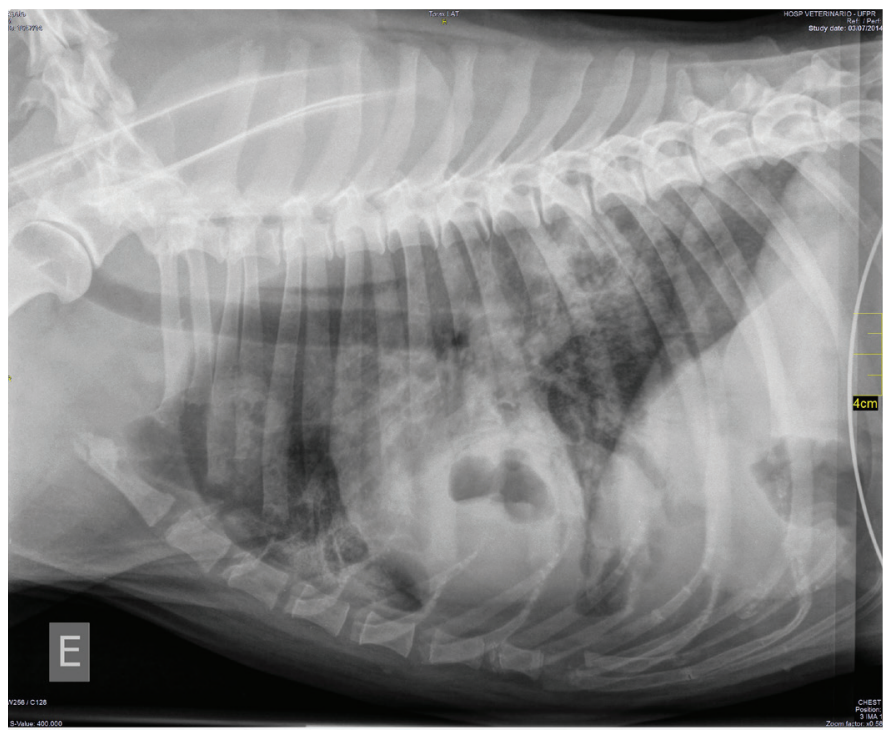

Fig.1. Left lateral radiograph of dog A with Cryptococcus neoformans shows a diffuse mixed pulmonary pattern with alveolar consolidation, multifocal cavitation and moderate enlargement of the tracheobronchial lymph nodes.

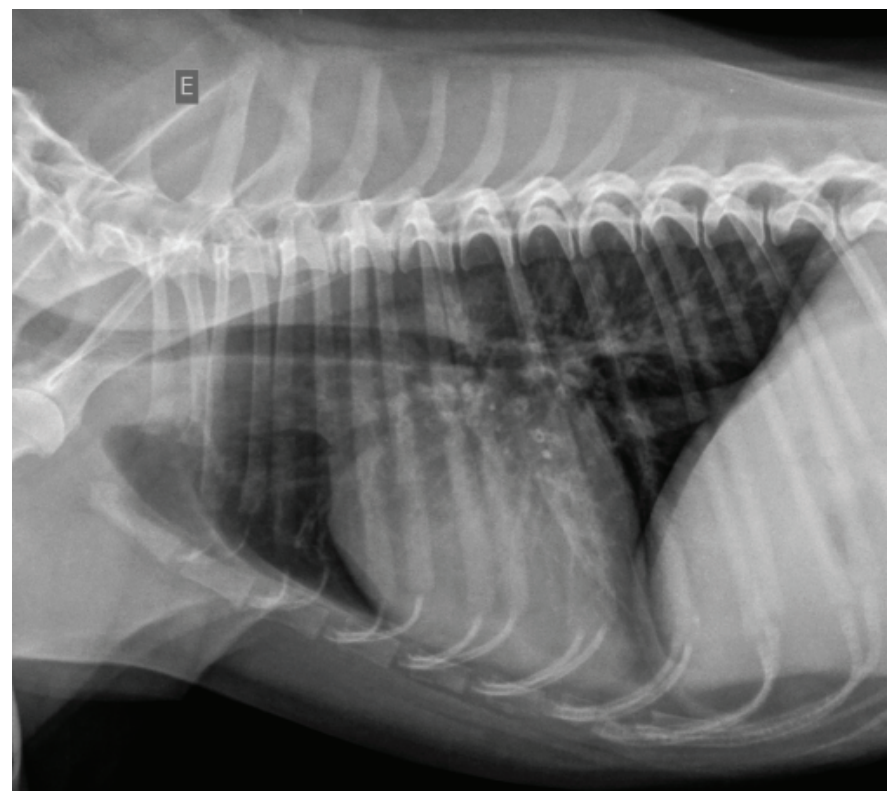

Fig.2. Left lateral radiograph of dog B with Candida parapsilosis associated with chronic bronchial disease shows a diffuse bronchial pattern. 
Table 1. Percentage of the differential cytological interpretation of the bronchoalveolar lavage fluid (BALF) of dogs $A$ and $B$

\begin{tabular}{cccccc}
\hline BALF & Macrophages & Neutrophils & Eosinophils & Lymphocytes & Mastocytes \\
\hline A & $23 \%$ & $59 \%$ & $7 \%$ & $11 \%$ & - \\
B & $6 \%$ & $70 \%$ & $20 \%$ & $4 \%$ & -
\end{tabular}

Reference values: macrophages $71 \%$, neutrophils $5 \%$, eosinophils $5 \%$, lymphocytes $17 \%$ and mastocytes $2 \%$ (English et al. 2009).

The BALF cytology analysis of dog A showed increased number of neutrophils and eosinophils been suggestive of inflammation process. Dog B cytology's also was suggestive of inflammation, presenting a significantly increase of neutrophils and eosinophils.

The BALF cultures were positive for fungi. In the agar blood plates of dog A had grown yeast with Cryptococcus characteristics, which was subsequently identified as Cryptococcus neoformans. In the agar Sabouraud plates of dog $\mathrm{B}$ had grown yeasts belonging to Candida species and was subsequently identified as Candida parapsilosis. Dog A had no chance of treatment with antifungals; he died 3 days after the BAL culture diagnosis. Necropsy was declined by the owner. Dog B received treatment for chronic bronchitis with oral (prednisolone) and nebulization (fluticasone) corticosteroids, bronchodilators and oral itraconazole for fungal pneumonia and presented complete resolution of clinical signs.

\section{DISCUSSION}

The incidence of fungal pneumonia in dogs and cats is not known in southern Brazil. This study showed a low incidence between May 2013 and Feb 2015; only two dogs out of 46 patients with respiratory clinical signs were positive for fungal pneumonia detected by BALF culture.

Among the fungi that can cause pneumonia, cryptococcosis has the largest number of cases reported in Brazil; however, case reports describe patients mainly with neurological signs (Marcasso et al. 2005, Martins et al. 2008, Campos et al. 2009, Galiza et al. 2014, Headley et al. 2016), one dog with cutaneous infestation (Martins et al. 2014) and another with nasal infection (Pereira et al. 2013). Dog A in this study, besides cough with no response to antibiotic treatment, had other clinical signs compatible with a mycotic disease, including fever, lymphadenopathy, and hyphema (Ferreira et al. 2007, Greene \& Bromel 2012, Hawkins 2014). The pulmonary manifestation is considered uncommon, whilst the nervous central system is most often affected, followed by the eyes (Ferreira et al. 2007). Cryptococcus sp. have recently emerged as opportunistic pneumonia in immunocompromised humans (Richardson 2005).

In veterinary medicine, information regarding candida pneumonia is limited. In humans, Candida sp. is one of the most common opportunistic fungal lung infections, mainly in immunocompromised patients (Limper 2010, Wilson et al. 2002). There are several case reports concerning disseminated candidiasis in dogs (Clercx et al. 1996, Rodriguez et al. 1998, Heseltine et al. 2003, Moretti et al. 2004, Brown et al. 2005, Skoric et al. 2011). Candida parapsilosis was identified in the BAL culture of dog B. This candida species is the second fungus most isolated from respiratory samples in humans (GarnachoMontero et al. 2013). The incidence of Candida pneumonia remains unrecognized in dogs and cats and requires studies focused on opportunistic fungi as they pose a serious health threat (Limper 2010).

Candida parapsilosis was reported in dogs and cats, causing urinary tract infections and cutaneous infections (Pressler et al. 2003). Dog B in this study had clinical signs, thoracic radiographs and BALF cytology consistent with chronic bronchitis. This dog had a previous history of steroid long term treatment for cough; it is believed this could be the cause of Candida in the BALF culture because, as abovementioned, systemic immunocompromised patients are susceptible to Candida infections (Silva 2010, Greene \& Bromel 2012). The dog in this study, received antifungal treatment because, although, the presence of fungi frequently only implies colonization of the respiratory tract it can represent an infection and discrimination between the two is difficult. Furthermore, delayed treatment initiation is associated with high mortality in humans (Garnacho-Montero et al. 2013).

Survey thoracic radiographs are commonly the first exam requested when pneumonia is suspected and this exam provides results that assist in selecting the next appropriate test (Cohn 2009). The thoracic radiographic findings of $\operatorname{dog} A$, were suggestive of a fungal disease since diffuse mixed pattern (interstitial, alveolar) with cavitation in lungs associated with hilar lymphadenopathy are describes as suspicious of fungal pneumonia (Thrall 2013). Although the most characteristic radiographic pattern of fungal pneumonia is the miliary interstitial nodular pattern, radiographic changes can vary greatly and include interstitial with an alveolar pattern or bronchointerstitial and consolidated regions of the lung (Reinero \& Cohn 2007, Thrall 2013, Hawkins 2014). A study of the radiographic appearance of pulmonary cryptococcosis in people, revealed a diffuse interstionodular pattern accompanying large cavities in some patients (Piyavisetpat \& Chaowanapanja 2005), as observed in the dog with cryptococcosis in this study. No distinguishing features were described about Cryptococcus sp. radiographic appearance in dogs and cats.

The diffuse bronchial pattern seen in the radiography of $\operatorname{dog} B$ is compatible with chronic bronchitis (McKiernan 2000, Hawkins 2014). Fungal pneumonia was not on the differential list since miliary or interstitial, neither alveolar pattern was identified (Thrall 2013). In humans, the radiographic appearance of Candida albicans pneumonia is described as alveolar or mixed alveolar and interstitial with the absence of miliary nodular pattern (Buff et al. 1982).

In this study, thoracic x-ray assisted in the diagnosis of both dogs but showed no radiographic signs suggestive of fungus pneumonia on dog B specifically. Thorax radiography is an important screening diagnostic method; however different diseases may reveal similar radiographic patterns and therefore it requires complementary diagnostic tools (Reinero \& Cohn 2007, Thrall 2013).

A BALF culture in humans is considered one of the main diagnostic methods with high sensibility and specificity for fungal identification in the respiratory system (Ashraf et al. 2008, Limper 2010, Silva 2010, Garnacho-Montero et al. 2013). In dogs and cats, this method has been used to diagnose numerous respiratory diseases, such as bacterial pneumonia, chronic bronchial diseases, neoplasia and hypersensitivity 
diseases (Hawkins et al. 1995, Foster et al. 2004, Johnson et al. 2013). It is believed that the incidence of fungal pneumonia in the region studied was really low because BALF has been described as a sensible method for diagnosis.

Although the cytological BALF analysis has previously been described for identifying pathogenic fungus with a $71 \%$ success rate (Hawkins \& DeNicola 1990), in this study, none fungal organisms were identified, even in the BALF cytology from the dog with positive culture. Cytology analysis revealed an increased number of neutrophils and eosinophils (Table 1), as described in the BALF of dogs with fungal pneumonia in the same study (Hawkins \& DeNicola 1990). Also, neutrophilic and eosinophilic BALF inflammation has also been reported in chronic bronchitis (McKiernan 2000, Melchert et al. 2008). Also with this BALF cytology results, bacterial pneumonia could be differential diagnosis, but bacterial pneumonia was discounted because neither dog had positive bacterial cultures and they did not improved the clinical signs with antibiotics.

The clinical significance of this study is the importance of retaining fungal pneumonia in the differentials diagnosis list for patients with respiratory clinical signs. It is believed that there is a possibility to have more animals affect with opportunistic or pathogenic fungus in daily clinical routine but are underdiagnosed. More veterinary medical research regarding fungal diseases in Brazil is required. These authors believe if there is a registration system would increase knowledge about mycotic epidemiology.

The limitation of this study was not performing a bronchoscopically-guided BAL method. While the nonbronchoscopic lavage is indicated in diffuse conditions, fungal organisms have been found in specimens from every lung lobe in only half of the dogs in which the organisms were found in lavage fluid (Hawkins \& DeNicola 1990). Hence, it is a possibility in our study, to have washed a non-affected lung lobe. A further limitation was not complementing the BAL with another diagnostic method, such as PCR, serologic test or fungal antigen to increase the sensibility and specificity of the diagnosis (Limper 2010).

\section{CONCLUSIONS}

The occurrence of fungal pneumonia in southern Brazil of dogs and cats throughout this study was relatively low.

The BAL fluid culture may allow diagnosis of fungal pneumonia caused by opportunistic or pathogenic fungi; this differential diagnosis in dogs and cats with pulmonary clinical signs should be a clinical concern.

Acknowledgements.- This study was supported by the National Counsel of Technological and Scientific Development (CNPq, proc. 471733/2013-0) and we would like to thank also the Coordination for the Improvement of Higher Education Personnel (CAPES) for the scholarship.

\section{REFERENCES}

Aidé M.A. 2009. Chapter 4--histoplasmosis. J. Bras. Pneumol. 35(11):1145-1151. http://dx.doi.org/10.1590/S1806-37132009001100013. PMid:20011851.

Andreasen C.B. 2003. Bronchoalveolar lavage. Vet. Clin. N. Am., Small Anim. Pract. 33(1):69-88. http://dx.doi.org/10.1016/S0195-5616(02)00056-6. PMid:12512377.
Ashraf M., Kotby A., Shaheen M., Basim H., El Masry A. \& Mansour M. 2008. Diagnostic bronchoalveolar lavage for pulmonary fungal infections in critically ill children. Pediatrics 121(Suppl.2):159-160. http://dx.doi. org/10.1542/peds.2007-2022FFFFFFF.

Brilhante R.S., Coelho C.G., Sidrim J.J., Lima R.A., Ribeiro J.F., Cordeiro R.A., Castelo-Branco Dde.S., Gomes J.M., Simões-Mattos L., Mattos M.R., Beserra H.E., Nogueira G.C., Pinheiro A.Q. \& Rocha M.F. 2012. Feline histoplasmosis in Brazil: clinical and laboratory aspects and a comparative approach of published reports. Mycopathologia 173(2/3):193-197. http://dx.doi. org/10.1007/s11046-011-9477-8. PMid:22006110.

Brömel C. \& Sykes J.E. 2005. Epidemiology, diagnosis and treatment of blastomycosis in dogs and cats. Clin. Tech. Small Anim. Pract. 20(4):233239. http://dx.doi.org/10.1053/j.ctsap.2005.07.004. PMid:16317913.

Brown G.D., Denning D.W., Gow N.A.R., Levitz S.M., Netea M.G. \& White T.C. 2012. Hidden killers: human fungal infections. Sci. Transl. Med. 4(165):165rv13. http://dx.doi.org/10.1126/scitranslmed.3004404. PMid:23253612.

Brown M.R., Thompson C.A. \& Mohamed F.M. 2005. Systemic candidiasis in an apparently immunocompetent dog. J. Vet. Diagn. Invest. 17(3):272-276. http://dx.doi.org/10.1177/104063870501700312. PMid:15945387.

Buff S.J., McLelland R., Gallis H.A., Matthay R. \& Putman C.E. 1982. Candida albicans pneumonia: radiographic appearance. AJR Am. J. Roentgenol. 138(4):645-648. http://dx.doi.org/10.2214/ajr.138.4.645. PMid:7039275.

Campos F.L., Pereira J.R., Silva M.V., Santos B.C.P. \& Baroni F.A. 2009. Isolamento de Cryptococcus neoformans, C. gatti e C. laurentii de sistema nervoso central de cães na cidade do Rio de Janeiro, RJ, Brasil. Acta Scient. Vet. 37:351-355.

Carneiro R.A., Lavalle G.E. \& Araújo R.B. 2005. Histoplasmose cutânea em gato: relato de caso. Arq. Bras. Med. Vet. Zootec. 57(Suppl.2):158-161. http://dx.doi.org/10.1590/S0102-09352005000800005.

Carvalho G.S. 2013. Aspergilose Pulmonar em Cão. Monografia em Medicina Veterinária, Universidade Federal de Campina Grande, Brasil. 30p.

Clercx C., McEntee K., Snaps F., Jacquinet E. \& Coignoul F. 1996. Bronchopulmonary and disseminated granulomatous disease associates with Aspergillus fumigatus and Candida species infection in a golden retriever. J. Am. Anim. Hosp. Assoc. 32(2):139-145. http://dx.doi.org/10.5326/15473317-32-2139. PMid:8680920.

Cohn L.A. 2009. Pulmonary parenchimal disease, p.78-144. In: Ettinger S.J. \& Feldman E.C. (Eds), Textbook of Veterinary Internal Medicine. 7 th ed. Saunders, St Louis.

Cordeiro R.A., Coelho C.G.V., Brilhante R.S.N., Sidrim J.J.C., Castelo-Branco D.S.C.M., Moura F.B.P., Rocha F.A.C. \& Rocha M.F.G. 2011. Serological evidence of Histoplasma capsulatum infection among dogs with leishmaniasis in Brazil. Acta Trop. 119(2/3):203-205. http://dx.doi.org/10.1016/j. actatropica.2011.05.007. PMid:21651884.

English K., Cowell R.L., Tyler R.D. \& Meinkoth J.H. 2009. Tracheal wash and bronchoalveolar lavage, p.256-276. In: Cowell R.L., Tyler R.D., MeinKoth J.H. \& DeNicola D.B. (Eds), Diagnostic Cytology and Hematology in Dogs and Cats. 4th ed. Mosby, St Louis.

Ferreira R.R. 2008. Pesquisa sorológica de Aspergillus fumigatus e cultivo fúngico de amostras obtida de cães com descarga nasal. Dissertação de Mestrado em Ciências Veterinárias, Universidade Federal do Rio Grande do Sul, Porto Alegre, Brasil. 60p.

Ferreira R.R., Machado M.L.S., Spanamberg A., Bianchi S.P., Aguiar J., Hummel J. \& Ferreiro L. 2007. Infecções fúngica do trato respiratório de cães e gatos. Acta Scient. Vet. 35(Suppl.2):285-288.

Foster S.F., Martin P., Braddock J.A. \& Malik R. 2004. A retrospective analysis of feline bronchoalveolar lavage cytology and microbiology (19952000). J. Feline Med. Surg. 6(3):189-198. http://dx.doi.org/10.1016/j. jfms.2003.12.001. PMid:15135356.

Galiza G.J.N., Silva T.M., Caprioli R.A., Tochetto C., Rosa F.B., Fighera R.A. \& Kommers G.D. 2014. Caracterísiticas histomorfológicas e histoquímicas determiantes no diagnóstico da criptococose em animais de companhia. 
Pesq. Vet. Bras. 34(3):261-269. http://dx.doi.org/10.1590/S0100736X2014000300011.

Garnacho-Montero J., Olaechea P., Alvarez-Lerma F., Alvarez-Rocha L., Blanquer J., Galván B., Rodriguez A., Zaragoza R., Aguado J.M., Mensa J., Solé A. \& Barberán J. 2013. Epidemiology, diagnosis and treatment of fungal respiratory infections in the critically ill patient. Revta Esp. Quimioter. 26(2):173-188. PMid:23817660.

Greene C.E. \& Bromel C. 2012. Histoplasmosis, p.612-614. In: Greene C.E. (Ed.), Infectious Disease. 4th ed. Saunders Elsevier, St Louis.

Hawkins E.C. \& DeNicola D.B. 1990. Cytologic analysis of tracheal wash specimen and bronchoalveolar lavage fluid in the diagnosis of mycotic infections in dogs. J. Am. Vet. Med. Assoc. 197(1):79-83. PMid:2370224.

Hawkins E.C. 2014. Respiratory system disorders, p.217-366. In: Nelson R.W. \& Couto C.G. (Eds), Small Animal Internal Medicine. 5th ed. Saunders Elsevier, St Louis.

Hawkins E.C., DeNicola D.B. \& Plier M.L. 1995. Cytological analysis of bronchoalveolar lavage fluid in the diagnosis of spontaneous respiratory tract disease in dogs: a retrospective study. J. Vet. Intern. Med. 9(6):386-392. http://dx.doi.org/10.1111/j.1939-1676.1995.tb03298.x. PMid:8558485.

Headley S.A., Mota F.C., Lindsay S., Oliveira L.M., Medeiros A.A., PrettoGiordano L.G., Saut J.P. \& Krockenberger M. 2016. Cryptococcus neoformans var. grubii-induced arthritis with encephalitic dissemination in a dog and review of published literature. Mycopathologia 181(7/8):595-601.http:// dx.doi.org/10.1007/s11046-016-0009-4. PMid:27126588.

Heseltine J.C., Panciera D.L. \& Saunders G.K. 2003. Systemic candidiasis in a dog. J. Am. Vet. Med. Assoc. 223(6):821-824. http://dx.doi.org/10.2460/ javma.2003.223.821. PMid:14507099.

Johnson L.R., Herrgesell E.J., Davidson A.P. \& Pappagianis D. 2003. Clinical, clinicopathologic and radiographic findings in dogs with coccidioidomycosis: 24 cases (1995-2000). J. Am. Vet. Med. Assoc. 222(4):461-466. http:// dx.doi.org/10.2460/javma.2003.222.461. PMid:12597419.

Johnson L.R., Queen E.V., Vernau W., Sykes J.E. \& Byrne B.A. 2013. Microbiologic and cytologic assessment of bronchoalveolar lavage fluid from dogs with lower respiratory tract infection: 105 cases (2001-2011). J. Vet. Intern. Med. 27(2):259-267. http://dx.doi.org/10.1111/jvim.12037. PMid:23363380.

Limper A.H. 2010. The changing spectrum of fungal infections in pulmonary and critical care practice. Proc. Am. Thorac. Soc. 7(3):163-168. http:// dx.doi.org/10.1513/pats.200906-049AL. PMid:20463243.

Lorigados C.A.B., Machado T.F., Zoppa A.M., Junior R.N., Rego A.B.A.S. \& Saragó A. 2012. Aspectos radiográficos e ultrassonográficos da coccidioidomicose pulmonar em cão: relato de caso. Vet. Zootec. 19:61-63.

Mandanas R.A. \& Byrd R.P. 2014. Fungal pneumonia overview of fungal pneumonia: overview of fungal pneumonia Medscape, New York. Available in <http://emedicine.medscape.com/article/300341-overview\#showall> Accessed on May 10, 2016.

Marcasso R.A., Sierra S., Arias V.B., Bracarense A.P.F.R.L., Yamamura A.A.M., Biasi F., Lopes B.A., Amude A.M. \& Cortez D.E.A. 2005. Criptococose no sistema nervoso de cães; relato de três casos. Semina, Ciênc. Agrárias 26(2):229-238. http://dx.doi.org/10.5433/1679-0359.2005v26n2p229.

Martins D.B., Barbosa A.L.T., Cavalheiro A., Lopes S.T.A., Santurio J.M., Schossler J.E. \& Mazzanti A. 2008. Diagnóstico de criptococcose canina pela citologia aspirativa por agulha fina. Ciência Rural 38(3):826-829. http://dx.doi. org/10.1590/S0103-84782008000300039.

Martins D.B., Deckmann M.A.J. \& Sperotto V.R. 2014. Criptococose cutânea associada à severa infestação por Sarcoptes sp. e Demodex sp. em um cão. Ciência Rural 44(8):1437-1441. http://dx.doi.org/10.1590/01038478cr20131128.

McKiernan B.C. 2000. Diagnosis and treatment of canine chronic bronchitis. Twenty years of experience. Vet. Clin. N. Am., Small Anim. Pract. 30(6):1267-
1278, vi-vii. http://dx.doi.org/10.1016/S0195-5616(00)06006-X PMid:11221981.

Melchert A., Motta Y.P., Giuffrida R. \& Laposy C.B. 2008. Avaliação citológica e microbiológica do lavado broncoalveolar em cães hígidos. Semina, Ciênc. Agrárias 29(1):157-164. http://dx.doi.org/10.5433/16790359.2008v29n1p157.

Moretti A., Posteraro B., Boncio L., Mechelli L., Gasperis E., Agnetti F. \& Raspa M. 2004. Diffuse cutaneous candidiasis in a dog: diagnosis by PCR-REA Revta Iberoam. Micol. 21(3):139-142. PMid:15709788.

Norris C.R. 2004. Fungal pneumonia, p.446-456. In: King L.G. (Ed.), Textbook of Respiratory Disease in Dogs and Cats. 5th ed. Saunders Elsevier, St Louis. http://dx.doi.org/10.1016/B978-0-7216-8706-3.50063-3.

O’Brien C.R., Krockenberger M.B., Wigney D.I., Martin P. \& Malik R. 2004. Retrospective study of feline and canine cryptococcosis in Australia from 1981 to 2001: 195 cases. Med. Mycol. 42(5):449-460. http://dx.doi.org/ 10.1080/13693780310001624547. PMid:15552647.

Oliveira I.A., Nobre M.O. \& Ferreiro L. 2005. Pesquisa de criptococose em cães atendidos no hospital de clínicas veterinárias na UFRGS, Porto Alegre, Brasil. Acta Scient. Vet. 33:253-258.

Paula D.A.J., Almeida A.B.P.F., Cruz F.S., Furlan F.H., Colodel E.M., Sousa V.R.F, Nakazato L. \& Dutra V. 2014. Occurrence and molecular characterization of cryptococcosis in dogs and cats in Mato Grosso, Brazil. Pesq. Vet. Bras. 34(2):167-172. http://dx.doi.org/10.1590/S0100-736X2014000200012.

Pereira M.F., Santos B.M., Silva V.C.L., Pereira H.N.S., Silva L.B.G., Paiva B.H., Barros R.B., Dias M.B.M.C., Neves A.K.R. \& Oliveira A.A.F. 2013. Aspectos clínicos e anatomopatológicos da criptococose nasal com disseminação sistêmica em cão: relato de caso. Med. Vet. 7:7-15.

Piyavisetpat N. \& Chaowanapanja P. 2005. Radiographic manifestations of pulmonary cryptococcosis. J. Med. Assoc. Thai. 88(11):1674-1679. PMid:16471118.

Pressler B.M., Vaden S.L., Lane I.F., Cowgill L.D. \& Dye J.A. 2003. Candida spp. Urinary tract infections in 13 dogs and seven cats: predisposing factors, treatment and outcome. J. Am. Anim. Hosp. Assoc. 39(3):263-270. http:// dx.doi.org/10.5326/0390263. PMid:12755200.

Queiroz J.P.A.F., Sousa F.D.N., Lage R.A., Izael M.A. \& Santos A.G. 2008. Criptococose: uma revisão bibliográfica. Acta Vet. Bras. 2:32-38.

Quinn P.J., Carter M.E. \& Markey B. 1994. Clinical Veterinary Microbiology. Wolf, London. 648p.

Reinero C.R. \& Cohn L.A. 2007. Interstitial lung diseases. Vet. Clin. N. Am., Small Anim. Pract. 37(5):937-947. http://dx.doi.org/10.1016/j.cvsm.2007.05.008

Ribas C.R., Dornbusch P.T., Cirio S.M., Rocha R.M.V.M., Capriglione L.G.A. \& Fam A.L.P.D. 2010. Citologia de lavado broncoalveolar de cães: comparação entre lâminas a fresco e conservadas em formol. Arch. Vet. Sci. 15(2):6976. http://dx.doi.org/10.5380/avs.v15i2.14880.

Richardson M.D. 2005. Changing patterns and trends in systemic fungal infections. J. Antimicrob. Chemother. 56(Suppl.1):5-11. http://dx.doi. org/10.1093/jac/dki218. PMid:16120635.

Rodríguez F., Fernández A., Monteros A.E, Wohlsein P. \& Jensen H.E. 1998. Acute disseminated candidiassis in a puppy associated with parvoviral infection. Vet. Rec. 142(16):434-436. http://dx.doi.org/10.1136/ vr.142.16.434. PMid:9595635.

Rudorf H., Taeymans H. \& Johnson V. 2008. Basics of thoracic radiography and radiology, p.1-19. In: Scharwrs T. \& Johnson V. (Eds), BSAVA Manual of Canine and Feline Thoracic Imaging. British Small Animal Veterinary Association, Shurdington.

Silva R.F. 2010. Fungal infections in immunocompromised patients. J. Bras. Pneumol. 36(1):142-147. http://dx.doi.org/10.1590/S180637132010000100019. PMid:20209317. 
Silva-Ribeiro V.L., Ferreira-da-Cruz M.F., Wanke B. \& Galvão-Castro B. 1987. Canine histoplasmosis in Rio de Janeiro: natural and experimental infections. J. Med. Vet. Mycol. 25(5):319-322. http://dx.doi.org/10.1080/02681218780000361. PMid:3430293.

Silveira E., Mottin I.B., Ehlers A. \& Marques S.M.T. 2016. Histoplasmose feline disseminada: relato de um caso. Publ. Med. Vet. Zootec. 10:207-211.

Skoric M., Fictum P., Slana I., Kriz P. \& Pavlik I. 2011. A case of systemic mycosis in a Hovawart dog due to Candida albicans. Vet. Med. 56(5):260 264. http://dx.doi.org/10.17221/1561-VETMED.

Souza E.W.S., Gremião I.D.F., Pereira S.A., Cunha S.C.S. \& Borba C.M. 2015. Feline histoplasmosis: a case of supraorbital involvement. Revta Bras. Ciênc. Vet., Heredia, 22:77-80.

Sylkes J.E. \& Malik R. 2012. Cryptococcosis, p.621-634. In: Greene E. (Ed.), Infectious Disease. 4 th ed. Saunders Elsevier, St Louis.

Teixeira F.S. 2012. Ocorrência de aspergilose pulmonar em cães com sintomatologia respiratória atendidos no HCV-UFRGS, Dissertação de Mestrado em Ciências Veterinárias, Universidade Federal do Rio Grande do Sul, Porto Alegre.
Thrall D.E. 2013. The canine and feline lung, p.608-631. In: Thrall D.E. (Ed.), Textbook of Veterinary Diagnostic Radiology. 6th ed. Saunders Elsevier, St Louis.

Togashi R.H., Aguiar F.M.B., Ferreira D.B., Moura C.M., Sales T.M. \& Rios N.X. 2009. Pulmonary and extrapulmonary coccidioidomycosis: three cases in an endemic area in the state of Ceará, Brazil. J. Bras. Pneumol. 35(3):275-279. http://dx.doi.org/10.1590/S1806-37132009000300013. PMid:19390727.

Wanke B., Lazera M.S., Monteiro P.C.F., Lima F.C., Leal M.J.S., Ferreira Filho P.L., Kaufman L., Pinner R.W. \& Ajello L. 1999. Investigation of an outbreak of endemic coccidioidomycosis in Brazil's northeastern state of Piaui with a review of the occurrence and distribution of Coccidioides immitis in three other Brazilian states. Mycopathologia 148(2):57-67. http://dx.doi. org/10.1023/A:1007183022761. PMid:11220226.

Wilson L.S., Reyes C.M., Stolpman M., Speckman J., Allen K. \& Beney J. 2002. The direct cost and incidence of systemic fungal infections. Value Health 5(1):26-34. http://dx.doi.org/10.1046/j.1524-4733.2002.51108.x. PMid:11873380. 